\title{
O PROCESSO DE FORMAÇÃO DO CONHECIMENTO PROFISSIONAL DOCENTE
}

\section{ARTIGO ORIGINAL}

BARBOSA, Monalisa Raymundo ${ }^{1}$

LEITÃO, Neir Lardo ${ }^{2}$

AMORIM, Gabriela de Castro Loech ${ }^{3}$

CALIL, Ana Maria Gimenes Corrêa ${ }^{4}$

PACHECO, Márcia Maria Dias Reis ${ }^{5}$

BARBOSA, Monalisa Raymundo. Et al. O processo de formação do conhecimento profissional docente. Revista Científica Multidisciplinar Núcleo do Conhecimento. Ano 05, Ed. 06, Vol. 01, pp. 159-181. Junho de 2020. ISSN: 2448-0959, Link de acesso: https://www.nucleodoconhecimento.com.br/educacao/processo-de-formacao

${ }^{1}$ Mestrado em andamento em Desenvolvimento Humano: Formação, Políticas e Práticas Sociais. Graduação em Pedagogia. Graduação em Letras.

${ }^{2}$ Especialização em Alfabetização: diferentes Linguagens. Graduação em Pedagogia. Graduação em Serviço Social.

${ }^{3}$ Graduação em Pedagogia.

4 Doutorado em Educação (Psicologia da Educação). Mestrado em Educação: Psicologia da Educação. Especialização em Psicopedagogia. Graduação em Pedagogia. Graduação em Economia.

5 Doutorado em Educação (Psicologia da Educação). Mestrado em Educação (Psicologia da Educação). Especialização em Psicopedagogia. Graduação em Pedagogia. 


\section{RESUMO}

O desenvolvimento profissional do professor é uma variável absolutamente necessária ao alcance da qualidade no ensino. O processo de formação do conhecimento profissional docente se dá ao longo de sua trajetória de vida e apresenta características próprias, diferentemente das demais profissões, devido a sua complexidade, e por oportunizar ao docente o contato com a profissão, antes mesmo que ele se decida seguir por ela. Entender o que pensam as professoras do ensino Infantil sobre tal processo formativo, e o que dizem as pesquisas sobre o tema, é o que busca a pesquisa qualitativa aqui apresentada, a qual foi construída a partir do resultado de uma entrevista estruturada realizada com cinco professoras de uma rede de ensino do Vale do Paraíba. Perante os resultados observados, busca-se oferecer elementos para a organização do percurso de formação continuada do docente, entendendo que este se dá nas interações vivenciadas pelo professor

Palavras-Chave: Conhecimento profissional, conhecimento docente, trajetória.

\section{INTRODUÇÃO}

A atualidade apresenta a realidade escolar centrada em complexos desafios sociais, econômicos e culturais, que impedem a escola à premente necessidade de mudanças e adaptações de suas ações, para dar conta de seu preponderante papel na sociedade do século XXI. A figura do professor, apontada, neste contexto, como variável fundamental para o sucesso do aluno, tem se tornado nas últimas décadas um ponto central das discussões que buscam identificar o foco inicial para as mudanças necessárias na Educação. Estas discussões têm por tema o percurso de formação do professor, desde a sua formação inicial, e seu desenvolvimento na formação continuada, buscando substanciar a questão de sua profissionalização, ao trazer à tona suas especificidades, que oscilam ainda quanto à visão que se tem da docência: vocação, ofício ou profissão. Centra-se nesta questão o desafio atual do papel do professor: firmar-se enquanto profissional, e desta forma receber a valorização pretendida. 
De acordo com os estudos de Tardif, Raymond (2000), os estudantes passam pela formação inicial e para o magistério sem modificar substancialmente suas crenças anteriores sobre o ensino. E, tão logo começam a trabalhar como professores, sobretudo no contexto de urgência e de adaptação intensa que vivem quando começam a ensinar, são essas mesmas crenças e maneiras de fazer que reativam para solucionar seus problemas profissionais

Para que a emersão da profissionalização do professor de torne cada dia mais evidente, vê-se a necessidade de centrar o olhar nos conhecimentos específicos do professor, que se inserem em uma "profissão exigente", apresentando suas características próprias que oportunizam ao professor construir seu desenvolvimento profissional para além de sua formação inicial ou continuada, especificamente, mas que se constrói num contínuo que segue paralelamente ao desenvolvimento pessoal.

\section{OBJETIVO}

Entender, à luz de referenciais teóricos, a forma como as professoras da Educação Infantil entrevistadas percebem como se deu o aprendizado de seu conhecimento profissional docente ao longo de sua trajetória.

\section{METODOLOGIA}

O tema deste estudo é resultado de discussões realizadas na disciplina de Políticas e Propostas de Formação Docente, do curso de mestrado Profissional em Educação da Universidade de Taubaté/SP, da turma de 2018.

A ação apresentada compreende uma entrevista com professoras da Educação Infantil de uma escola pública, para que se manifestem sobre sua trajetória enquanto docentes, o que pode ter influenciado na constituição de seu conhecimento profissional, e como percebem este percurso.

Considerada como "o instrumento por excelência da investigação Social", a entrevista, segundo Lakatos (2003) nos apresenta, é uma ação entre entrevistado e entrevistador, para que este colha informações relativas a determinado tema, sendo 
assim realizada uma conversação profissional, por meio da qual serão retirados dados que esclareçam alguma questão. Caracteriza-se pela comunicação face a face a partir de critérios metódicos (LAKATOS, 2003, p.195).

Entre os tipos de entrevista, optou-se pela entrevista Padronizada ou Estruturada. Nesta, o entrevistador segue determinado roteiro fixo, pré-determinado, para que o entrevistador não se desvie dos objetivos da investigação, e para que os resultados possam refletir aspectos com relação a diferentes respostas, sem que a forma de fazer as perguntas venham conduzir o entrevistado a respostas diferenciadas, sobre o mesmo tema. Essa técnica de pesquisa permite a obtenção de dados de natureza qualitativa para a pesquisa científica (LAKATOS, 2003, p.196).

Foram selecionadas 5 professoras, que atuam na educação Infantil de uma escola de rede pública municipal, tendo como critério de escolha as que se manifestaram voluntariamente para responder a entrevista, a partir de um convite feito pela gestora da unidade, mediante esclarecimento do objetivo da pesquisa. Os participantes foram orientados que se trata de uma pesquisa para um trabalho em grupo na Universidade, e que os dados serão sigilosos, não sendo identificados os participantes e nem divulgada qualquer informação sobre a escola ou pessoas que eventualmente forem citadas nos relatos. Para organização dos resultados, determinaram-se nomes fictícios para as professoras, sem que houvesse qualquer tipo de relação com os seus verdadeiros nomes.

\section{O ROTEIRO}

Como parte da técnica de coleta de dados escolhida e para o sucesso do estudo, o roteiro para a entrevista deve ser previamente elaborado e constar no planejamento da pesquisa, devendo para isso seguir os critérios para sua organização. Lakatos (2003, p.164) nos apresenta que devem ser levados em conta na organização do material de pesquisa o preparo prévio do material propriamente dito, e a organização do material que será usado para análise e reflexão. Este último será embasado nos referenciais estudados na disciplina de Políticas e Propostas de Formação Docente, anteriormente mencionada, e elencados como referências. 
Quanto ao roteiro para a entrevista, foi organizado conforme mostra o quadro 1.

Quadro 1- Roteiro para entrevista

\begin{tabular}{|c|c|}
\hline OBJETIVOS & QUESTÕES \\
\hline $\begin{array}{l}\text { Recuperando a } \\
\text { trajetória para a } \\
\text { escolha da profissão }\end{array}$ & $\begin{array}{l}\text { Como se deu a sua trajetória de vida pessoal até } \\
\text { você escolher ser professora? }\end{array}$ \\
\hline $\begin{array}{l}\text { Recuperando } \\
\text { memória formativa }\end{array}$ & $\begin{array}{l}\text { Qual a relação existente entre a trajetória da sua vida } \\
\text { pessoal e escolar e a professora que você é hoje? } \\
\text { Como é que isso pode ter contribuído para a } \\
\text { professora que você é? }\end{array}$ \\
\hline $\begin{array}{l}\text { Contribuições de } \\
\text { vivências no meio } \\
\text { escolar }\end{array}$ & $\begin{array}{l}\text { Você percebe uma relação entre a sua vivência } \\
\text { enquanto aluna da Educação Básica e a professora } \\
\text { que você é hoje? }\end{array}$ \\
\hline $\begin{array}{l}\text { Reflexão sobre } \\
\text { atuação }\end{array}$ & Como você se percebe enquanto profissional? \\
\hline $\begin{array}{l}\text { Concepções } \\
\text { crenças sobre } \\
\text { profissão docente }\end{array}$ & O que é para você ser uma boa professora? \\
\hline
\end{tabular}

Fonte: Elaborado pelas autoras.

\section{VISÃO GERAL DO TEMA}

Ao apresentar aspectos relacionados à trajetória, formação, influência das vivências escolares, e as percepções sobre o conhecimento profissional, como suporte para a análise da entrevista com as professoras, pretende-se identificar razões para suas posturas e concepções, acreditando que estas variáveis constituem o profissional e interferem em suas concepções e, consequentemente, em suas práticas.

Entender a trajetória das práticas de ensino nos possibilita identificar traços de períodos remotos, muitas vezes ainda presentes nas falas e ações dos professores 
na atualidade. Considerar que todos passaram por bancos escolares e que esta vivência traz inflências significativas para a atuação, justifica o olhar neste aspecto, para desvelar que tipo de ensino o profissional vivenciou. Parace ser importante identificar que elementos relevantes o professor traz em sua memória e que seriam capazes de agir como elemento influenciador de suas práticas. Ou, ainda, entender como o professor superou, ou não, aquelas vivências que não tenham surtido exemplos que realmente possam ser seguidos nos padrões de ensino de qualidade atuais.

Observa-se, conforme nos apresenta Morgado (2011), que a construção do conhecimento do professor não se dá de forma linear, em pontos estanques, mas sim num contínuo de sua trajetória, de forma progressiva e contiuada. Assim são desenvolvidas suas competências, identidade e profissionalização, as quais vão se incorporando em suas ações ao longo de sua carreira (MORGADO, 2011).

O processo de construção do conhecimento do professor se dá à medida que o professor exerce sua ação, interage e reflete, em um eixo de formação que fundamenta sua prática em movimentos de sucessivas aproximações e recuos dos objetivos de sua função.

A partir destas perspectivas, apresenta-se a importância do entendimento da trajetória do professor para se entender a formação de seu conhecimento profissional.

\subsection{TRAJETÓRIA}

Considera-se que a evolução do ensino moderno, conforme nos assegura Tardif (2013), pode ser dividida em três grandes períodos, denominados de idade da vocação, compreendida entre os séculos XVI ao XVIII; idade do ofício, observada a partir do século XIX chegando até meados do século XX, de onde de inicia a idade da profissão.

Tardif (2013) apresenta em suas pesquisas que, tendo como pano de fundo a reforma protestante e a contrarreforma católica, nos séculos XVI e XVIII, o ensino se 
organizava como uma missão religiosa, com o objetivo de estudar e divulgar os preceitos bíblicos, e a ação do professor/religioso era considerada como uma "profissão de fé".

Nóvoa (1995) nos relata que no século XVIII o ensino deixou de ter caráter religioso e passou a ser mais estatal, pois até então a função de professor não era profissionalizada, e por isso eram os religiosos que ocupavam essa função. A intermediação do Estado levou a uma equalização dos grupos que tinham o ensino como ocupação principal.

A descrição das regras para a nomeação de professores foi uma grande preocupação dos reformadores do século XVIII. Ao Estado coube a estratégia de formar um corpo de professores submetidos à sua disciplina. $O$ seu funcionamento deveria ser uma vontade partilhada entre o Estado e os docentes; isso assegurava um estatuto de autonomia e independência aos professores. No final do século XVIII, só era permitido ensinar se houvesse uma licença ou autorização do Estado. Um conjunto de atributos era exigido; o documento era a garantia do Estado para os docentes, compondo um perfil de profissional competente.

Considerada por Tardif (2013) como idade do ofício, este período começa a exigir uma formação específica para se exercer o magistério. A partir do século XIX, os docentes passaram a reivindicar a inter-relação entre fatores sociais e profissionais, argumentando que a ação educativa é um trabalho de importância social e especializado. Essa etapa permitiu a profissionalização e a estabilidade da imagem do docente.

Nesse sentido, uma grande conquista se deu pela criação das escolas normais. Nas palavras de Nóvoa (1995, p.18): "origem de uma verdadeira mutação sociológica do corpo docente: o 'velho' mestre-escola é definitivamente substituído pelo 'novo' professor de instrução primária".

Na metade do século XIX, perante a visão dos professores como indivíduos, deu-se a feminização do professorado. 
Após a Segunda Guerra Mundial, o ensino como ofício se estabelece e se inicia seu processo de democratização; os professores são integrados à função pública e passam a ser regidos por estatutos do funcionalismo público, o que lhes garante certa autonomia em suas ações, com respeito a interferências/controles de "pais, sacerdotes ou notáveis" (TARDIF, 2013, p. 557).

No século $X X$, o movimento educação nova foi a consequência de uma lenta evolução cultural, que determinou socialmente a ideia de escola e o produto das ciências da educação, e contribuiu para a configuração do modelo profissional do docente. Assim, Nóvoa (1995) aborda a crise da profissão docente, indicando as consequências do mal-estar que ataca os docentes: a autodepreciação junto com a desconfiança em relação à qualidade de trabalho. O mesmo autor revela, porém, que o valor positivo atribuído à profissão permanece intacto. Assim, observa-se que muito se tem escrito sobre a influência das mudanças sociais na educação, nas escolas e no trabalho dos professores.

Garcia (2009) entende a docência como a profissão do conhecimento, reconhecendo o saber como justificativa para o trabalho docente, transformando assim o conhecimento em aprendizagem. Para o autor, conhecimentos e alunos se transformam em uma velocidade maior, sendo necessário o reforço dobrado para aquisição do conhecimento docente que venha a dar conta de seus desafios.

Tardif (2013) ressalta que, para a concretização da atual idade da profissão no ensino, faz-se necessário que se fortaleçam as condições de trabalho do docente e que seja dada uma atenção ao seu processo de formação, fortalecendo a base de conhecimentos próprios para o ensino.

Nos últimos anos, Nóvoa (2017) apresenta um estudo do crescimento dos sentimentos de insatisfação das ambições teóricas versus a realidade da escola e dos professores; o autor mostra-se preocupado pelo fato de que as universidades pouco estão contribuindo para a transformação das condições sócio profissionais dos professores. 
Nóvoa (2017) chama a atenção para nossa realidade educacional e define o momento que estamos passando como um tempo de "privatização da educação", caracterizado por salários baixos; difíceis condições de trabalho escolar; intensificação de ações, burocráticas e de controle para o professor, com discursos por melhor remuneração versos baixos resultados de "aprendizagem" dos alunos.

O mesmo autor salienta que estamos diante de um cenário que pretende desmantelar o sistema universitário de formação para professores, com um conjunto de programas que, segundo o autor, vão piorar a situação da escola pública. O número desenfreado de escolas particulares e escolas a distância que surgiram; a intenção de gestão privada; a contratação de empresas pelas redes públicas, bem como a contratação de empresas privadas nas ações pedagógicas, curriculares e formativas, já denunciam segundo o autor atitudes de total enfraquecimento dos rumos da Educação Pública.

Nesse entendimento, Nóvoa (2017) salienta a importância da formação profissional como matriz da formação para uma profissão. Essa formação deve ser realizada em um ambiente institucional híbrido, que atenda ao encontro e à junção das várias realidades que configuram o campo docente. Para ele, no momento atual já não cabem queixas, mas coragem, com iniciativas de mudança; trata-se de preencher o vazio que temos entre universidade e escola, para que possamos pensar na formação do professor, na sua afirmação como profissional e no seu reconhecimento perante as pessoas.

Ainda segundo Nóvoa (2017), é necessário constituir um local de formação de caráter híbrido, um local onde possamos ligar a universidade e as escolas públicas às políticas públicas; um local comum, com pessoas da escola e da universidade, que possuam capacidade formadora, com visão técnica, e valorizando a prática. Esse lugar deve estar entrelaçado à formação do professor, totalmente vinculada com a dimensão profissional baseada na aprendizagem, numa espécie de reflexão e pesquisa; convergência e colaboração. E, para finalizar, um local de ação pública, onde a sociedade esteja presente e participe trazendo humanidade para esse local; 
valorizando tanto os conhecimentos práticos do ambiente escolar, quanto as teorias basilares da universidade.

\subsection{FORMAÇÃO}

Garcia (2009), a partir de suas pesquisas, apresenta as principais características que devem orientar as ações de formação para o desenvolvimento profissional do docente. Para ele, são aquelas que se embasam nas concepções construtivistas, que considerem o professor como sujeito ativo deste processo, envoltas em processos de avaliação, observação e reflexão sobre ações práticas. Sendo o aprendizado construído a longo prazo, as experiências formativas devem permitir entrelaçar os conhecimentos novos com os conhecimentos prévios do professor, de forma que estejam relacionadas em sua prática e em seu contexto de sala de aula e escola, de onde deve partir a motivação para a busca de melhoria de suas ações e onde resultados serão associados às mudanças de processos coletivos, ligados diretamente à mudança da cultura escolar, oportunizando a criação colaborativa de novas teorias e novas práticas pedagógicas.

À medida que se aprimora o desenvolvimento profissional do professor, é criada também a sua identidade profissional, que está relacionada à forma como estes profissionais se percebem, se definem, constituindo o seu "eu profissional". Essa identidade é construída ao longo de sua trajetória profissional, sendo marcada por suas vivências junto aos seus pares, nos espaços e contextos de ação, e a partir dos resultados de suas ações. A questão que marca a identidade do profissional ligada ao seu aprimoramento se assenta não somente na reflexão de "quem eu sou?"; de uma forma mais abrangente a questão passa a ser "quem eu quero ser?". A partir desta reflexão, o profissional faz uma autoavaliação de suas ações em contexto, buscando identificar suas motivações, seus compromissos, reconhecendo sua satisfação com relação a seu trabalho e às influências que interferem em suas ações, quanto aos aspectos pessoais, sociais e cognitivos (GARCIA, 2009).

O processo de aprendizagem dos professores se constitui em diferentes etapas, que se inserem em seu processo de desenvolvimento profissional. 
As etapas da formação inicial, inserção e desenvolvimento profissional deveriam estar muito mais inter-relacionadas, de forma a criar aprendizagens coerentes e um sistema de desenvolvimento da profissão docente [...] $\mathrm{O}$ assumir a perspectiva de aprendizagem ao longo da vida obriga a maioria dos países a darem um maior apoio aos seus professores nos primeiros anos de ensino e a proporcionarem-lhes incentivos e recursos para um desenvolvimento profissional contínuo. De uma maneira geral, seria mais adequado melhorar a inserção e o desenvolvimento profissional dos professores ao longo da sua carreira, em vez de aumentar a duração da formação inicial (OCDE, 2006, p. 13).

O desenvolvimento profissional oportuniza ao docente a necessária reflexão sobre sua prática, de forma que possa se desenvolver enquanto profissional e consequentemente enquanto pessoa, considerando que estas variáveis - "desenvolvimento profissional" e "processos de mudança" - caminham unidas. A mudança, que acontece no processo de desenvolvimento profissional, está relacionada às crenças, ou seja, proposições e premissas que os professores têm sobre o que consideram como verdadeiro e trazem consigo e que, por sua vez, interferem em suas concepções e práticas. Essas crenças são construídas a partir de experiências vividas pelo professor, as quais se constituem em três categorias: as experiências pessoais, a experiência baseada em conhecimento formal, e a experiência escolar e de sala de aula já vividas por ele enquanto aluno ao longo de sua trajetória.

\subsection{CONTRIBUIÇÕES DE VIVÊNCIAS NO MEIO ESCOLAR}

Falar das possíveis contribuições oriundas das vivências do contexto escolar se faz pertinente a partir dos estudos de Nóvoa (2017), quando ele traz o conceito das "comunidades profissionais docentes", e demonstra através de suas pesquisas a necessidade do enriquecimento da práticas através do envolvimento em processos de inovação pedagógica ou da pesquisa, e, ainda, da integração e participação ativa desses profissionais. O autor destaca a total importância de o professor compreender as várias identidades que existem na profissão docente e sobretudo na construção 
identitária como um processo, constituído dentro de um contexto organizado e num local que the faça sentido. A construção da postura, do desenvolvimento interior do professor, segundo o autor, é adquirida a partir da sua forma de agir, sua capacidade de encontrar novas formas de atuar, e de sua intervenção pública.

Nóvoa (2017) e Schulman (2013) afirmam a necessidade de se atentar para algumas etapas que são fundamentais à base do conhecimento da profissão do professor, à interposição profissional: os professores com outros professores reconhecendo-se como formadores e colaboradores de suas potencialidades; a consciência da corresponsabilidade entre professor iniciante e professor experiente; a indução profissional, caracterizada pela união de fato do trabalho desses profissionais, de suas trocas de sua exposição quanto ao trabalho de qualidade. Estes autores partilham da mesma opinião quando tratam sobre a escola e a sociedade na atualidade; ambos esperam que o profissional da atualidade reconheça a escola como um local democrático, que compartilhe uma visão do todo, na importância da pluralidade e o bem comum. O professor necessita saber intervir como professor, com consciência crítica, no sentido de compreender que há um conhecimento a ser ensinado e que essas responsabilidades não se esgotam.

\subsection{O CONHECIMENTO PROFISSIONAL}

Apesar da importância e especificidade do conhecimento dos professores, necessários para sua ação, Tardif (2013) ainda o considera situado em um campo de pesquisas estagnado, por se inserir em um concepções fragmentadas por múltiplas teorias, sendo que "[...] há tantas concepções e definições sobre o conhecimento dos professores, quanto correntes de pesquisa sobre a questão" (TARDIF, 2013, p.567). Mesmo diante desta ressalva, a autora indica que tal conhecimento não se constitui por saberes meramente teóricos, devendo partir da prática e da observação; são também conhecimentos que partem das interações com os alunos, sendo influenciados por seus contextos e que se ancoram em experiências de suas vidas e de trabalho, sendo por eles "reinterpretados" em função das necessidades apresentadas. 
Já para Schulman (2013), as características centrais da base de conhecimento para o ensino estão totalmente ligadas à compreensão da responsabilidade da eficácia que o professor deve ter para passar o conteúdo que precisa ser ensinado, além de sua consciência na forma e na compreensão flexível da diversidade do aluno.

Ainda, segundo o autor, para atingir todos os objetivos da escolarização, o professor deve estar cercado de seus materiais, como currículos, sequências, escopos, materiais, normas institucionais, mecanismos, elementos com os quais os professores necessitam estar à vontade. Schulman acredita que possamos ter uma abordagem técnica do conhecimento "[...], porém sem perder a alma, [...] o raciocínio pedagógico é tão parte do ensino, quanto o próprio ato de ensinar" (SCHULMAN, 2013, p. 219).

\section{A CONSTRUÇÃO DO CONHECIMENTO PROFISSIONAL: O QUE DIZEM AS PROFESSORAS}

Como proposta da ação de pesquisa, as cinco professoras da Educação Infantil foram ouvidas sem que houvesse interferências em suas respostas, para que pudessem se manifestar livremente. Observa-se que cada qual manteve suas características quanto as suas fundamentações. Algumas mais espontâneas, outras mais técnicas, porém todas com as mesmas condições para elaborar suas respostas. Nos quadros que se seguem, foram transcritas as respostas, tendo sido apenas compiladas de forma organizada quanto aos temas, para facilitar as devidas análises.

Quadro 2 - Entrevista sobre sua trajetória

\section{1- Como se deu a sua trajetória de vida pessoal até você escolher ser professora?}

"Desde pequenininha gostava de brincar de escolinha e por isso fui fazer magistério."

Prof. Ana 
"Eu tive muitos bons professores durante toda a trajetória; meu tio sempre foi um exemplo, ele é um professor já faz bastante tempo, também tem uma prima professora. Minha mãe fez magistério, então durante todo esse tempo foi se formando, mas quando estava no ensino médio não sabia o que iria fazer. $E$ aí eu queria ficar um ano parada mas a minha mãe não deixou; ela falou que tinha que fazer alguma coisa. $E$ aí ela veio e escolheu por mim e foi uma boa escolha, porque eu me encontrei na pedagogia. Daí durante a faculdade eu quase desisti, mas consegui terminar e deu tudo certo."

\section{Prof. Bia}

"Então né, eu ... trajetória que eu trabalhei de várias funções, já fui atendente de loja, já fui atendente de lanchonete, e aí para passar o tempo terminei o segundo grau. $E$ aí na dúvida, ainda tinha dúvidas a respeito do que eu ia fazer, mas eu sempre gostei de dar aula; quando eu lembro, quando era criança, eu já brincava de escolinha e depois que eu cresci foi amadurecendo diante dessa profissão. E eu acho muito interessante... você vê retorno, vê o crescimento mesmo da criança e pode contribuir de uma forma positiva. E ai... decidi fazer pedagogia, e graças a Deus sou muito feliz na escolha que eu fiz, com essa profissão docente. Dessa maneira eu trabalhei de várias outras experiências, né?... Eu cheguei também a exercer uma função de instrutor, onde eu tinha que planejar, e não só a mim, todos os funcionários. Então já tinha também essa coisa de empatia, de me colocar no lugar do próximo, de planejar o que eu ia dar para o treinamento deles e aí mais tarde eu resolvi fazer pedagogia."

\section{Prof. Carla}

"Os meus pais, eles nunca tiveram oportunidade de estudar. Então, eles vieram lá do Pernambuco, e aí eu acompanhei durante toda minha infância como que era a vida deles. Eles nunca tiveram essa 
oportunidade e eles valorizavam muito educação, me incentivam a sempre tá me esforçando ... sempre buscar crescer profissionalmente, então eu sempre contei com esse apoio e por ter acompanhado toda essa trajetória deles, de não ter tido essa oportunidade de estudar, eu me motivei. Ser professora para ajudar eles também e para ajudar outras pessoas."

Prof. Deli

"Desde pequena costumava brincar de escolinha e eu sempre fazia questão de ser a professora; gostava de "fazer atividades" para eles e durante toda minha vida fui cercada por bons professores, profissionais atentos e competentes. Na minha família há muitas professoras; cheguei a pensar em fazer contabilidade, fiz até vestibular, mas não a matrícula, porque achei que era bom trabalhar com alguma profissão que eu gostava.

Prof. Ema

Fonte: Elaborada pelas autoras.

Pode-se destacar nas falas das professoras a presença de relatos emocionais ligados à vocação e ao lúdico nas lembranças evocadas da ação docente. Percebem-se ligações afetivas também com as dificuldades familiares, que influenciaram a tomada de decisões ou mesmo o anseio de mudança de perspectivas. Mahoney e Almeida (2010) enfatizam em seus estudos que o resgate das memórias afetivas e a reflexão sobre elas são meios pelos quais o professor pode adquirir clareza da repercussão das suas ações sobre aqueles a quem pretende ensinar.

A família foi apontada como algo importante na construção de si mesmo, representando o outro. Isso ajuda a dar base para o professor se construir como pessoa e como profissional. Segundo os estudos de Henri Wallon, o "eu" para se construir vive em constante conflito, em busca da diferenciação do eu e do outro; para Wallon, esse conflito propicia a construção da pessoa, pois sem ele não é possível se 
construir, desenvolver-se, tampouco transformar-se por meio da busca incessante de se firmar, de se reconhecer como pessoa plena, completa. Isso ocorre em um movimento centrípeto, pois estamos sempre nos desenvolvendo, buscando nossa construção (WEREBE, 1986).

A figura do professor é idealizada como que para acolher a quem está em dificuldades, ou mesmo como a de uma vida mais fácil, leve, do que a vivenciada na realidade. É atribuído ao professor um valor além de sua capacidade técnica para ensinar, conforme aponta Garcia (2009, p. 15): "As crenças têm funções afectivas e valorativas, atuando como filtro de informação que influencia a forma como se usa, guarda e recupera o conhecimento. Por outro lado, também predizem condutas."

Estas características são observadas nas falas que descrevem os elementos motivadores da escolha da profissão:

"Desde pequenininha gostava de brincar de escolinha." (Ana)

"bons professores [...] meu tio sempre foi um exemplo [...] uma prima professora, minha mãe fez magistério [...]eu queria ficar um ano parado mas a minha mãe não deixou." (Bia)

"trabalhei de várias funções, já fui atendente de loja, já fui atendente de lanchonete [...] quando era criança, eu já brincava de escolinha [...] eu trabalhei de várias outras experiências [...] função de instrutor (Carla)

"acompanhei durante toda minha infância como que era a vida deles" (Deli)

"Desde pequena costumava brincar de escolinha e eu sempre fazia questão de ser a professora, gostava de "fazer atividades [...]bons professores, profissionais atentos [...] na minha família há muitas professoras [...] pensar em fazer contabilidade, fiz até vestibular" (Ema) 
É evidente o sonho de se tornar professora, como pode ser observado; percebe-se uma satisfação em lecionar e o fato permite o desenvolvimento de sentimentos e perspectivas que valorizam a descoberta positiva da carreira. Nota-se claramente a influência familiar na escolha da profissão; a pesquisa de Raymond, Butt e Yamagishi (1993) in Tardif (2000) identifica que a vida familiar e as pessoas significativas na família aparecem como fonte de influência muito importante, que modela a postura da pessoa toda em relação ao ensino. As experiências escolares anteriores e as relações determinantes com professores contribuem também para modelar a identidade pessoal dos professores e seu conhecimento prático.

Quadro 3- Contribuição para sua trajetória

2- Qual a relação existente entre a trajetória da sua vida pessoal e escolar e a professora que você é hoje? Como isso pode ter contribuído para a professora que você é?

"[...] no meio do caminho tinha muitas professoras boas e acho que isso contribui bastante né?... para que eu fosse uma boa professora também." Prof. Ana

"Então, quando eu já tive vários bons exemplos ... eu peguei as coisas que eu achava que eram coisas que eu gostaria de ser né, como professora, até nos estágios ... Eu vi algumas professoras na escola e eu via se eu quero fazer isso eu não quero fazer. Também me aperfeiçoando, também como Coaching, que me ajudou muito né, entendeu? Superfícies algo mudar a conseguir manter melhor na sala. Na igreja eu ficava com as crianças ... elas também ajudavam bastante a ter mais autonomia, então quando eu entrei na sala de aula eu não "tava" com mais medo; eu realmente já "tava" confiante de que eu ia fazer alguma coisa que desse certo."

Prof. Bia 
“Eu acho que é essa questão que nem eu falei na pergunta anterior na resposta anterior, é questão de você terminar empatia, né? de se colocar no lugar do outro, te fazer entender, né? Hoje em dia quando eu estou nessa profissão, eu quero ser muito de forma que as crianças vão aprender melhor, de que forma eu posso melhorar, se não tá sendo alcançado o objetivo, é de que forma eu posso melhorar aquilo, mas sempre me colocando no lugar deles e eu acho que isso é importante também para o desenvolvimento.

\section{Prof. Carla}

“Eu sempre gostei do ambiente escolar então isso de certa forma sempre me motivou porque eu sempre gostei desse ambiente de estudo, de ensinar, isso sempre me motivou."

Prof. Deli

“Como disse anteriormente, tive bons exemplos de professores. Em 1996,

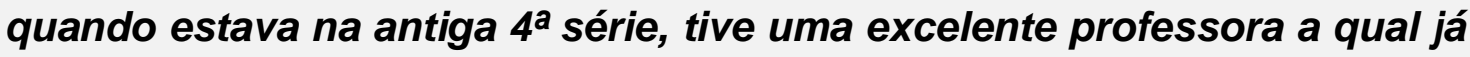
trabalhava no âmbito de projetos, ela nos inspirava a querer e ser melhor, durante toda minha escolarização tive modelos que contribuíram para minha vida profissional."

\section{Prof. Ema}

Fonte: Elaborado pelas autoras.

Algumas falas das professoras, nos remetem para as influências no processo de construção de seus conhecimentos, que tiveram ao longo de suas trajetórias, conforme afirmam Morgado (2011), Nóvoa (2017), Tardif, Raymond (2000), quando estas trazem da memória alguns exemplos como:

"muitas professoras boas" (Ana); "eu já tive vários bons exemplos"; "eu peguei as coisas que eu achava que eram coisas que eu gostaria de ser 
né"; "Na igreja eu ficava com as crianças"; "até nos estágios"; "ambiente escolar" (Bia); " quando estava na antiga 4a série"; "professora a qual já trabalhava no âmbito de projetos". (Ema)

Podemos identificar a percepção das professoras de tais influências em suas ações atuais. Percebe-se que na trajetória de vida, seu crescimento como pessoa e como profissional seguem em paralelo, conforme aponta Morgado (2011), e assim vão sendo formadas suas competências, identidade e profissionalização, que vão se incorporando em suas ações ao longo de sua carreira. Relativamente às falas das professoras Ana, Bia e Ema, conforme salientou Marcelo Garcia (2009) em seus estudos, os professores iniciam suas trajetórias de estudo com as crenças pessoais acerca do ensino, com imagens de bom professor que tiveram, imagem de si mesmos como estagiários, e a memória de si mesmo como alunos. Essas crenças e imagens pessoais geralmente permanecem sem alterações ao longo do programa de formação e acompanham os professores durantes suas práticas de ensino.

Quadro 4 - Relação e vivência

3- Você percebe uma relação entre a sua vivência enquanto aluna da Educação Básica e a professora que você é hoje?

"Bons exemplos a gente sempre guarda. Então o que eu via de bom eu faço hoje e tento me aperfeiçoar."

Prof. Ana

"Com certeza! A gente vê muito que a gente já viveu e o que a gente passa aqui né? Então que eu como professora vendo os professores, que foram meus professores, como aluna ... Então né eu lembro quando eu "tava" na creche, algumas coisas que passavam por lá e eu vejo que os alunos repetem sempre as mesmas coisas aqui, então se faz a gente ter um pouco mais de paciência, entender que eles são crianças que não dá para a gente... Muda o âmbito né? Porque eu trabalhava no fundamental. Ensino Infantil você tem que entender que a criança ela não vai ficar o 
tempo todo sentada. Esse tipo de coisa me faz lembrar como foi a minha infância e ter mais paciência com eles."

\section{Prof. Bia}

"Você falando agora eu me recordei. Eu lembro que eu tinha um professor de matemática, o nome dele era Teodoro, e eu era apaixonada por esse professor, eu já me espelhava nele, acho que também já veio daí né? Eu falei da minha infância; eu gostava de brincar de dar aulas; eu tinha uma admiração muito grande por esse professor, e eu acho que veio daí. Tem essa relação de afetividade, de carinho entre professor e o aluno, e eu gostava muito, era de matemática, é minha fraqueza matemática até hoje. Mas eu gostava muito desse professor, e até hoje é um professor profissional que eu me recordo dele e eu tenho sim um pouco do que ele também tinha na época... era criança, seja carinhoso, atencioso, gostava mesmo de ensinar."

\section{Prof. Carla}

"Sim. Eu sempre fico lembrando daqueles professores que marcaram minha infância e eu uso eles até hoje como referência; sempre que eu me lembro de alguns que marcaram realmente eu sempre volto... ver por eles também.

\section{Prof. Deli}

"Sim, em alguns aspectos socioafetivos, a relação à qual recebi tento passar para os meus alunos. Segundo Vygotsky, uma referência para nós pedagogas, este vínculo de afetividade é muito importante para o desenvolvimento dos alunos, através da interação entre professor e aluno a aprendizagem se torna significativa e prazerosa."

Prof. Ema 
Fonte: Elaborada pelas autoras.

sentimento e a lembrança das professoras marcados por bons professores levaramnas a usá-los como referência em sua vida escolar. Tardif (2002) chama de saberes experienciais, pois, ao longo de sua de vida pessoal e escolar, o futuro professor interioriza muitos conhecimentos, competências, crenças, valores, que assim vão estruturando sua personalidade e suas relações com os outros, e que são reutilizados de maneira não reflexiva mas com convicção na prática de seu ofício; são saberes experienciais do professor de profissão, baseados em aprendizagens herdadas da história escolar. Identifica-se a influência da vivência enquanto alunas da educação básica, em várias das falas registradas:

"Bons exemplos a gente sempre guarda"; "o que eu via de bom eu faço hoje"; "A gente vê muito que a gente já viveu e o que a gente passa aqui né"; "vendo os professores, que foram meus professores, como aluna"; "Eu lembro que eu tinha um professor de matemática[...] eu já me espelhava nele"; "uma admiração muito grande por esse professor, e eu acho que veio daí"; "Eu sempre fico lembrando daqueles professores que marcaram minha infância e eu uso eles até hoje como referência"; "a relação à qual recebi tento passar para os meus alunos".

Estas indicações apresentam traços das apropriações feitas pelas professoras enquanto vivenciaram a ação de outros professores e trazem para suas ações traços da "cultura, valores, práticas, característicos da profissão [...] parte fundamental da dinâmica pela qual indivíduos e os grupos compreendem os elos, mesmo imaginários, que os mantém unidos." (MORGADO, 2011, p.798).

As professoras identificam aprendizados a partir de observações de outros em sua prática.

Quadro 5 - Profissional

\section{4- Como você se percebe enquanto profissional?}


"Acredito que eu seja uma boa professora."

Prof. Ana

"acredito que ainda tenho que aprender... muito, né? Eu tô o tempo todo me construindo, então eu começo por um caminho, quando eu vejo que não é esse caminho eu vou conserto e começo a fazer por outro, ... não tenho dificuldade em tentar melhorar o tempo todo, que como eu acabei de começar. Então os professores em si acabam me ajudando, olha faz isso, faz aquilo... quando eu entrei tava muito mais perdida! Agora eu já sei, eu tenho uma rotina para os meus alunos e coisas, dicas que eu fui recebendo durante esse tempo com eles. Nesse pouco tempo foi me ajudamos, porque agora eu já sei o que eu tenho que fazer quando você pega o semanário, eu não entendia nada que... sabe, que lá não entendia o contexto o que que eu tinha que fazer, agora eu já sei o que que é cada coisa que cada base Então você vai né vai se construindo

\section{Prof. Bia}

"Como enquanto profissional... ser uma pessoa bem comprometida com a minha profissão, me percebo uma pessoa assim aberta a melhorar, aberta a opiniões construtivas. Eu sou uma pessoa que sempre reflito no que eu tenho feito, como eu tenho tentado passar para as crianças aquilo que a gente quer. Ao passar, me percebo como um professor bem reflexivo, necessário.

Prof. Carla

"Eu gosto muito de me esforçar, mas dizer que eu sempre vejo que eu posso tá melhorando sempre, então eu vejo o quanto eu ainda tenho que aprender. Um pouco que eu já sei, isso me faz querer crescer mais.

Prof. Deli 
“Me inspiro muito na teoria de Emília Ferreiro e Capovilla, onde trabalho na perspectiva construtivista e método fônico. Tento ser afetiva com os meus alunos e acredito ser muito dedicada e atenta à heterogeneidade de cada turma e respectivamente a cada criança. Tenho intencionalidade no desenvolvimento e aplicação das atividades."

Prof. Ema

Fonte: Elaborada pelas autoras.

Observam-se na autorreflexão sobre ser uma boa professora características técnicas apontadas em processos de formação, que nos levam a inferir sobre uma resposta evasiva que reflete a falta de compreensão sobre como se define um bom professor:

"ainda tenho que aprender... muito, né? Eu tô o tempo todo me construindo"(Bia); "uma pessoa bem comprometida com a minha profissão"; "aberta a melhorar "; "bem reflexivo" (Carla); "gosto muito de me esforçar" (Deli); "trabalho na perspectiva construtivista e método fônico, tento ser afetiva"; "ser muito dedicada e atenta à heterogeneidade"; "intencionalidade" (Ema).

Somente Ana foi bastante direta em sua resposta: "uma boa professora" (Ana).

A respeito da pouca reflexão sobre si, Garcia (2009, p.11) aponta a questão da identidade profissional como "a forma como os professores se definem a si mesmos e aos outros [...] crenças, os valores, o conhecimento sobre a matéria que ensinam, as experiências passadas, assim como a própria vulnerabilidade profissional". Confirmando as palavras de Garcia (2009, p.12), ao se definirem, as professoras trazem uma mistura do que são e do que deveriam ser. É como se houvesse a possibilidade de mudança de enfoque da pergunta de "Quem sou eu, neste momento?" para: "quem é que eu gostaria de ser?".

Observando a fala da prof. Bia, é possível ver o quanto as orientações sobre o funcionamento da escola são importantes no início da carreira do profissional docente, 
sobretudo ao considerar que o período de iniciação na carreira configura-se num momento de transição de estudante para professor. Garcia (1999) ressalta que é nessa fase que os docentes precisam adquirir conhecimentos profissionais, tornandose assim evidente que as regras, as informações sobre o sistema de ensino e as orientações sobre direitos e deveres, sugeridos passo a passo, fazem parte do rol de conhecimentos profissionais.

Ao evidenciar a relevância da ajuda dos colegas de trabalho, para assim diminuir suas dificuldades, e como resultado aprender com eles, Bia constata a importância da colaboração e de socialização de experiências, que podem conduzir o conjunto de professores a uma prática mais efetiva. Nesse sentido, Nóvoa (2009) ressalta a necessidade de uma formação continuada de professores, construída dentro da profissão, baseada em uma combinação de contributos científicos, pedagógicos e técnicos, desde que tenha como âncora os próprios professores, sobretudo os professores mais experientes.

A construção profissional do docente se faz a partir desses momentos e permanece durante toda a sua carreira; assim os processos de formação têm grande importância, permitindo a reflexão sobre a prática, o contexto, a escola, os alunos e o referencial teórico que sustenta a prática. Esse processo tem sentido na medida em que caminha com o processo de formação profissional. "Portanto, o saber não é uma substância ou um conteúdo fechado em si mesmo; ele se manifesta através de relações complexas entre o professor e seus alunos" (TARDIF, 2002, p.13).

Fica evidente a dualidade entre os saberes de sua formação acadêmica e a realidade com a qual se deparam ao iniciarem sua atuação profissional. Assim, Garcia e Vaillant (2012) afirmam: "[...] os docentes principiantes necessitam ter um conjunto de ideias e habilidades críticas, assim como a capacidade de refletir, avaliar e aprender sobre seu ensino, de tal forma que melhorem continuamente como docentes" (GARCIA e VAILLANT, 2012, p. 127). O relato aponta a consciência de que o professor precisa estar em um processo constante de formação. 
Quadro 6 - Ser uma boa professora

5- $O$ que é para você ser uma boa professora?

"A que é amiga dos alunos, a que tenta fazer todas as experiências, mas deixar para os alunos aprenderem o máximo possível, deixar eles exploraram bastante."

Prof. Ana

"Acredito que tem que ter equilíbrio, ao mesmo tempo você tem que ter o conhecimento e você também tem que ter paciência. Então tem que ter os três ao mesmo tempo para você conseguir ter uma sala boa, né?

Prof. Bia

"Uma boa professora tem tudo a ver com as respostas anteriores. Pensar na sua prática, você tem uma boa relação com seus alunos, se colocar no lugar deles, buscar... sempre estar se atualizando, buscar sempre melhorar a sua prática em sala de aula. Eu acho que é um comprometimento mesmo."

\section{Prof. Carla}

"Seria aquela que sempre está buscando novos conhecimentos, aquela que sempre se esforça para ajudar os alunos porque sempre a gente tem desafios, que vai de aluno para aluno. Então olhar para as diferenças e tentar buscar a melhor forma de lidar com as necessidades de cada aluno. É um desafio... então sempre a gente tem que estar se esforçando, buscando novas alternativas para poder "tá" melhorando no nosso profissional."

Prof. Deli 


\begin{abstract}
"Trabalhar em uma perspectiva interacionista, considerar o que o aluno já sabe e completar com o que posso pra que sua aprendizagem seja significativa e eficiente, envolver diversos recursos didáticos, considerando o modo de aprender de cada educando (auditivo, visual ou cinestésico).
\end{abstract}

Prof. Ema

Fonte: Elaborada pelas autoras.

Tardif (2013) apresenta os conhecimentos dos professores não como saberes meramente teóricos, devendo partir da prática sua observação; são também conhecimentos que partem das interações com os alunos, sendo influenciados por seus contextos, e que se ancoram em experiências de suas vidas e de seu trabalho, sendo por eles "reinterpretados" em função das necessidades apresentadas. Observamos nas respostas das professoras alguns dos aspectos apontados como definição de uma boa ação docente:

"que é amiga dos alunos"; "que tenta fazer todas as experiências" (ANA); "ter equilíbrio"; "ter o conhecimento e você também tem que ter paciência."; "boa relação com seus alunos, se colocar no lugar deles" (Bia); "olhar para as diferenças" (Deli); "Trabalhar em uma perspectiva interacionista"; "o que posso pra que sua aprendizagem seja significativa e eficiente, envolver diversos recursos didáticos, considerando o modo de aprender de cada educando (auditivo, visual ou cinestésico)." (EMA).

Garcia (2009) destaca o papel do bom professor como aquele que faz as necessárias transposições didáticas, levando o aluno às aprendizagens: "O conhecimento, o saber, tem sido o elemento legitimador da profissão docente e a justificação do trabalho docente tem-se baseado no compromisso em transformar esse conhecimento em aprendizagens relevantes para os alunos." (GARCIA, 2009, p.8).

Para que o conhecimento do professor se renove, com vistas a atender às demandas de sua atuação, ou seja atender ao direito do aluno de aprender, é preciso que este 
entenda a necessária ação para ampliar, aprofundar, melhorar a sua competência profissional e pessoal.

Garcia (2009) afirma que pesquisas atuais apontam a relação direta entre a qualificação do professor e os resultados de aprendizagem dos alunos. Como evidencia, observam-se mais diferenças de resultados em uma mesma escola, com alunos de um mesmo cível socioeconômico, pertencentes a uma mesma comunidade, do que entre escolas. A formação do professor se torna uma variável fundamental, quando se objetiva a qualidade de aprendizado dos alunos, sendo importante que se reflita sobre os processos de construção, manutenção e aprimoramento de suas aprendizagens, de modo que constitua seu repertório de competências para exercer sua ação profissional. O aprimoramento constante constitui o desenvolvimento profissional do professor que se estabelece a partir de uma reflexão sobre sua prática, de forma que esta resulte na identificação de possibilidades de mudanças que venham trazer maiores e melhores resultados na aprendizagem dos alunos.

O empenho do professor em buscar conhecer sua turma e abrir-se para o diálogo e as interações com seus pares faz parte do desenvolvimento de suas ações; além disso, para Rudduck (1991, p. 129, apud GARCIA, 2009, p.9), também é fundamental que o professor seja capaz de "manter a curiosidade acerca da sua turma; identificar interesses significativos nos processos de ensino e aprendizagem; valorizar e procurar o diálogo com colegas experientes como apoio na análise de situações".

As experiências e os conhecimentos adquiridos durante os anos, para Tardif (2002), caracterizam-se como saberes práticos ou experienciais, os quais advêm da prática cotidiana da profissão, não sendo adquiridos nas instituições de formação de professores e não estando sistematizados em teorias. Eles possibilitam ao professor fazer o julgamento da sua formação inicial ou continuada, pois o exercício da docência irá permitir a reflexão à luz da teoria e o ajuste da teoria à prática. 
É notória a preocupação das professoras quanto aos diversos tipos de dificuldades dos alunos, usando a reflexão para aperfeiçoamento sobre sua prática e suas dificuldades. Nesse sentido, Roldão (2006 b) afirma que:

Dominar esse saber, que integra e mobiliza, operando a convergência que permite ajustá-lo a cada situação, é sim alguma coisa de específico, que se afasta do mero domínio dos conteúdos como da simples ação relacional e interpessoal (ROLDÃO, 2006b apud ROLDÃO, 2007).

E, ainda, Roldão (2007, p. 101) explica que "o professor profissional - como o médico ou o engenheiro nos seus campos específicos - é aquele que ensina não apenas porque sabe, mas porque sabe ensinar".

A definição de que o bom professor é o que mobiliza seus conhecimentos para fazer as boas transposições didáticas, que levem de fato o aluno às aprendizagens, ou seja, que sabe de fato ensinar, não se apresenta explícita nas falas das professoras entrevistadas, sendo destacados somente os aspectos relacionais.

\section{CONSIDERAÇÕES FINAIS}

No estudo aqui relatado, a partir da análise das reflexões das professoras da educação infantil, observou-se como elas percebem o próprio processo de aprendizado de sua ação como docente. Ficou claro que identificam traços de influência de situações remotas de sua infância, enquanto "brincavam de escolinha"; que idealizam a figura do professor a partir de traços eminentemente emocionais, ou mesmo a partir da convivência com pessoas próximas que atuavam na profissão e marcaram de alguma forma a trajetória de suas vidas. O professor, sempre identificado como figura de destaque, muitas vezes como alguém capaz de mudar a história de vida por sua atuação, serviu de inspiração para as professoras fundamentarem suas escolhas. Durante a trajetória profissional, observou-se também a importância da figura de profissionais mais experientes que serviram de modelos de prática, ou mesmo para que as professoras pudessem tirar suas dúvidas ou buscarem soluções para as situações do cotidiano. 
A análise das respostas também permitiu associá-las com os referenciais teóricos que teorizam a construção do conhecimento profissional do docente como uma ação continuada, que se estabelece ligada à trajetória de vida pessoal dos indivíduos e que vai de adensando na medida que este estabelece suas interações no trajeto de sua ação enquanto profissional, quer seja com outros profissionais, quer seja com formadores em ações pontuais de seu processo de escolarização, e ainda diretamente na relação com os próprios alunos, em que a prática é aplicada a partir dos diferentes contextos e seus saberes são reinterpretados sempre que necessitam de ajustes para que resultem em eficácia.

Destarte, pôde-se concluir que os saberes que os professores mobilizam em sua ação profissional não são saberes meramente teóricos, mas um conjunto que se constitui a partir de uma prática fundada pela ação-reflexão-ação e pela observação de modelos competentes, os quais os professores necessitam cada vez mais conhecer, para se apropriar de suas soluções positivas, na constituição de sua própria prática significativa, entendendo que a construção de seus saberes é uma ação coletiva desenvolvida dentro de uma comunidade de aprendizagem: a escola.

\section{REFERÊNCIAS}

GARCIA, M. Desenvolvimento Profissional: passado e futuro. SÍSIFO: Revista de Ciências da Educação. n. 8, p. 7- 22, jan/abr., 2009.Disponível em:< http://www.unitau.br/files/arquivos/category_1/MARCELODesenvolvimento_Profissio nal_Docente_passado_e_futuro_1386180263.pdf> Acesso em 15/11/2018.

A identidade docente: constantes e desafios. Formação docente. Belo Horizonte, vol.01, n.01, p. 109-131, ago/dez, 2009. Disponível em: http://www.educadores.diaadia.pr.gov.br/arquivos/File/setembro2013/quimica_artigo s/a_ident_docent_constant_desaf.pdf Acesso em 15/11/2018.

. Formação de professores para uma mudança educativa. Portugal: Porto Editora, 1999. 
LAURINDA, R. Como me Constituí Professora: Explicitando o Implícito. Revista Ciências Humanas. Taubaté-SP, v. 7, n. 1, p. 4-26, jan-jun/2014.

LAKATOS, E. M.; MARCONI, E. M. A. Fundamentos de metodologia científica. 5. ed. São Paulo: Atlas, 2003.

MAHONEY, A. A.; ALMEIDA, L. R. (Org). Henri Wallon: Psicologia e Educação. 10. ed. São Paulo: Edições Loyola, 2010.

MENKAIKÁ. Revista Terra Mística. 11/09/2012. Disponível em: http://despertarcoletivo.com/geometria-sagrada-o-significado-da-espiral/ Acesso em $04 / 11 / 2018$

MORGADO, J.C. Identidade e profissionalidade: sentidos e (in)possibilidades Ensaio: aval. pol. públ. Educ. Rio de Janeiro, v. 19, n. 73, p. 793-812, out./dez. 2011. Disponível em:<http://www.scielo.br/pdf/ensaio/v19n73/04.pdf> Acesso em $01 / 11 / 2018$.

NÓVOA, A. O passado e o presente dos professores. In: NÓVOA, A. (org). Profissão professor. Porto: Porto Editora, 1995.

. Professores: Imagens do futuro presente. Lisboa: EDUCA, 2009.

- Firmar a posição como professor, afirmar a profissão docente. Cadernos de Pesquisa. São Paulo, v. 47, n. 166, p. 1106-1133, out./dez. 2017. Disponível em: < http://www.scielo.br/pdf/cp/v47n166/1980-5314-cp-47-166-1106.pdf> Acesso em15/11/2018.

. Firmar a posição como professor, afirmar a profissão docente. Cadernos de Pesquisa. São Paulo, v. 47, n. 166, p. 1106-1133, out./dez. 2017. OCDE, 2005.

OCDE. Professores são importantes: atraindo e retendo professores eficazes. Organização para Cooperação e Desenvolvimento Econômico. São Paulo. Editora Moderna, 2006. 
ROLDÃO, M C. Função docente: natureza e construção do conhecimento profissional. Revista Brasileira de Educação, v. 12, n. 34, p. 94-103, jan./abr., 2007

TARDIF, M.; RAYMOND, D. Saberes, tempo e aprendizagem do trabalho no magistério. Educação \& Sociedade, n. 73, Dezembro/2000.

TARDIF, M. Saberes docentes e formação profissional. Petrópolis, RJ: Vozes, 2013.

A profissionalização do ensino passados trinta anos: dois passos para a frente, três para trás. Educação \& Sociedade, Campinas, vol. 34, n. 123, p. 551-571, abr-jun. 2013. Disponível em:< http://www.scielo.br/scielo.php?pid=S010173302013000200013\&script=sci_abstract\&tlng=pt> Acesso em 15/11/ 2018

SHULMAN, L. Conhecimento e ensino: fundamentos para a nova reforma. Cadernos Cenpec. São Paulo, v.4, n.2, p.196-229, dez. 2013. Disponível em: < http://www.uepg.br/formped/disciplinas/OrganizacaoTrabalho/Texto\%202\%20Shulm an.pdf> Acesso em 15/11/2018.

WEREBE, M. J. G.; NADEL-BRULFERT, J. (Org.). Henri Wallon. São Paulo: Ática, 1986.

VAILLANT, D.; MARCELO, C. Ensinando a ensinar: as quatro etapas de uma aprendizagem. Curitiba: Editora UTFPR, 2012.

Enviado: Novembro, 2019.

Aprovado: Junho, 2020. 